\title{
ЕКСПЕРИМЕНТАЛЬНЕ \\ ТА ТЕОРЕТИЧНЕ ДОСЛІДЖЕННЯ ЛАЗЕРНОЇ ДЕСОРБЦЇ/ІОНІЗАЦІЇ МЕТИЛЕНОВОГО БЛАКИТНОГО З ПОВЕРХНІ ТЕРМОРОЗШИРЕНОГО ГРАФІТУ
}

\author{
В.О. ГАБОВИЧ, В.О. ПОКРОВСЬКИЙ, Є.М. ДЕМ'ЯНЕНКО, \\ А.Г. ГРЕБЕНЮК
}

Інститут хімії поверхні ім. О.О. Чуйка НАН України

(c) 2012

(Вул. Генерала Наумова, 17, Київ 03164)

Виміряно мас-спектри продуктів лазерної десорбції/іонізації барвника метиленового блакитного з поверхні терморозширеного графіту. Зокрема, показано, що в мас-спектрах найбільш інтенсивними є іони $[\mathrm{M}+1]^{+},[\mathrm{M}+2]^{+},[\mathrm{M}+3]^{+}$, з приєднаними до молекулярного іона одним, двома або трьома атомами водню. Експериментальні результати підтверджуються квантовохімічними розрахунками можливих продуктів, які можуть утворюватись під дією лазерного випромінювання.

\section{1. Вступ}

У сучасній мас-спектрометрії з лазерною десорбцією/іонізацією (ЛДІ) важливим є пошук нових матеріалів, які можуть бути використані як підкладки. В цьому сенсі цікаво, що, попри широке використання в науці та техніці різних графітоподібних матеріалів, більшість графітових похідних майже не охарактеризована 3 точки зору їх придатності для мас-спектрометричних застосувань. Тому відповідні дослідження є актуальними й можуть виявитися практично корисними. Поміж означених матеріалів особливо перспективним видається терморозширений графіт (ТРГ) [1]. Цей матеріал забезпечує ефективну іонізацію під дією лазерного опромінення і є технологічно придатним для вказаних застосувань. Внаслідок цього, використовуючи ТРГ підкладки, можна успішно досліджувати адсорбовані сполуки методом ЛДІ [2].

\section{2. Об'єкти та методи дослідження}

Зразки терморозширеного графіту можна одержати різним способом [1]. Для кожної окремої технології отримання ТРГ на поверхні утворюються різні функціональні групи, що необхідно мати на увазі, аналізуючи результати експериментів.
Барвник метиленовий блакитний (МБ) $є$ доволі добре вивченою сполукою як 3 точки зору масспектрометричних експериментів [3, 4], так і з огляду на методи квантової хімії $[5,6]$. Тому цей реагент варто використовувати як тестову речовину для дослідження і порівняння властивостей різних підкладок в мас-спектрометрії.

У даному дослідженні використовувалися зразки терморозширеного графіту, одержані шляхом обробки графіту сірчаною кислотою. Експерименти проводили на мас-спектрометрі Autoflex II фірми Bruker Daltonics. На пластинки, вирізані з ТРГ, наносився розчин МБ в етиловому спирті. Зразки витримувалися певний час при кімнатній температурі до висихання. Після цього їх розміщували в камері, де тиск зменшувався приблизно до $5,4 \cdot 10^{-7}$ Па. На зразки діяли лазерним випромінюванням. Іони, які утворювалися над поверхнею, під дією електричного поля потрапляли у часопрольотний аналізатор приладу. Отримані мас-спектри характеризувалися різним співвідношенням маси до заряду сполук, що й становить сутність вибраного мас-спектрометричного методу [7]. Було використано різні режими роботи лазера: від 40 до 100 відсотків його максимальної інтенсивності. Також варіювався час затримки екстракції іонів від 20 до 150 нс.

Для інтерпретації результатів було застосовано методи квантової хіміі. А саме, розрахунки виконано методом Хартрі-Фока з використанням базисного набоpy 6-31G (d,p) в межах програми USGAMESS [8]. Рівноважна просторова будова молекул реактантів, продуктів розглянутих реакцій визначались мінімізацією норми градієнта [9]. Про стаціонарність отриманих енергетичних мінімумів відповідних структур свідчила відсутність від'ємних власних значень відповідних матриць Гессе, згідно з теоремою Маррела-Лейдлера [10]. Енергія Гіббса відповідних реакції визначалась 

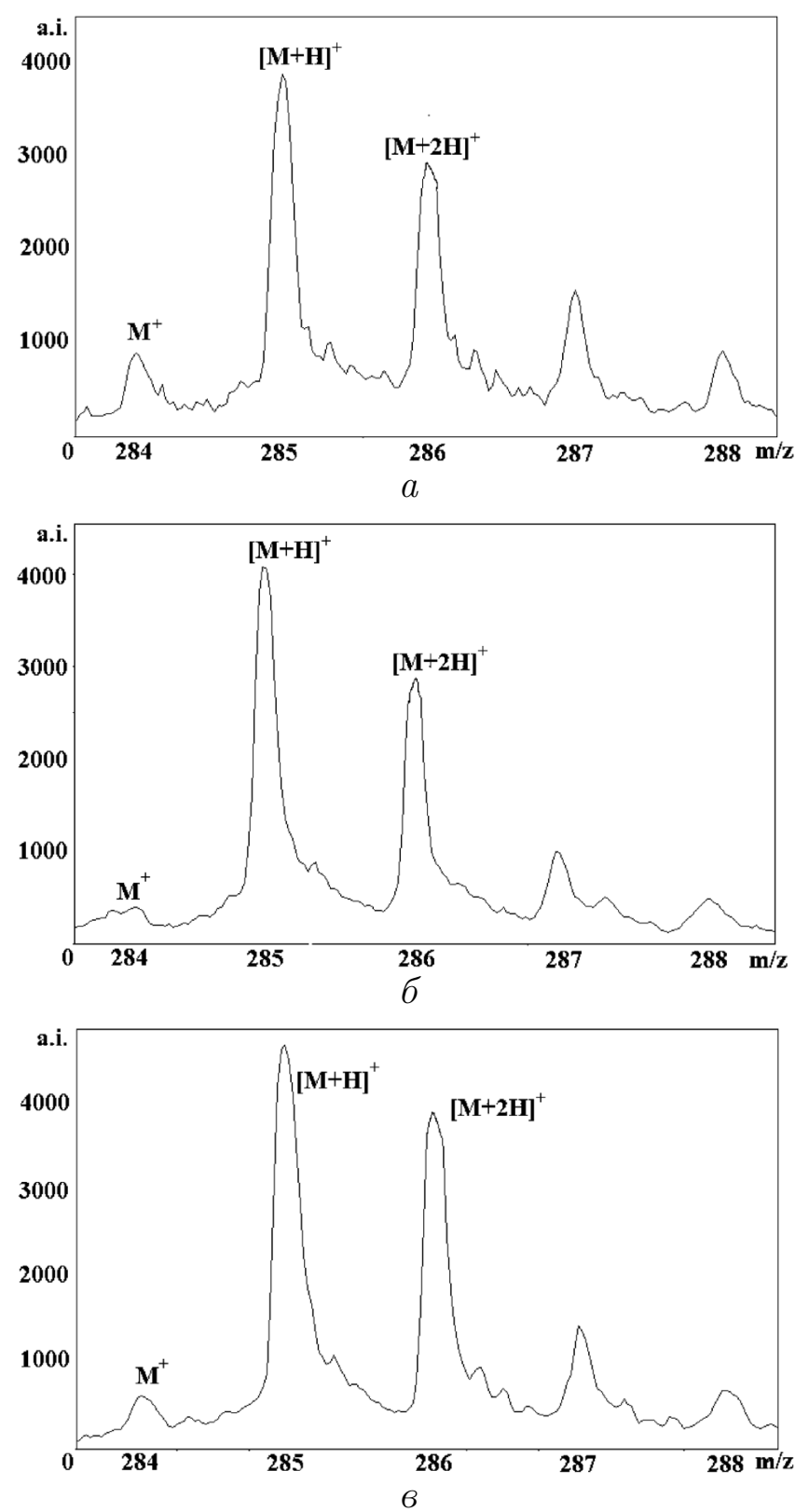

Рис. 1. Мас-спектри метиленового блакитного (МБ), отримані шляхом лазерної десорбції/іонізації з поверхні терморозширеного графіту (ТРГ): $a$ - при інтенсивності лазера $40 \%$ від максимальної потужності та часі затримки екстракції 20 нс; б - при інтенсивності лазера $60 \%$ та часі затримки 20 нс; в інтенсивності лазера $100 \%$ та часі затримки 20 нс

за формулою $\Delta G_{\text {реакції }}=\Delta G_{298 \text { (продукти реакції) }}^{0}-$ $\Delta G_{298 \text { (реактанти) }}^{0}$, де $\Delta G_{298}^{0}=E_{0 K}+\mathrm{ZPE}+G_{0 \rightarrow 298 \mathrm{~K}}$, $E_{0} \mathrm{~K}$ - повна енергія відповідної оптимізованої структури, ZРE - енергія нульових коливань, а величини $G_{0 \rightarrow 298} \mathrm{~K}$ знаходилися шляхом розрахунку матриці

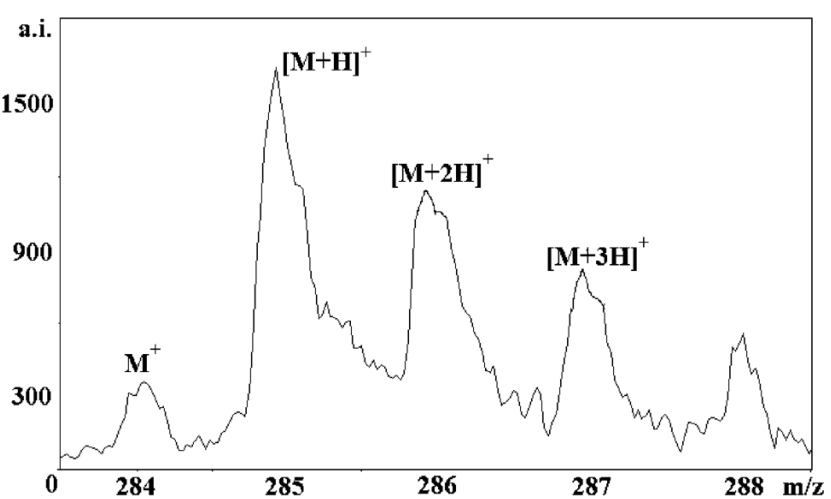

Рис. 2. Мас-спектр МБ, отриманий шляхом лазерної десорбціі/іонізації з поверхні ТРГ при інтенсивності $40 \%$ та часі затримки екстракції 150 нс

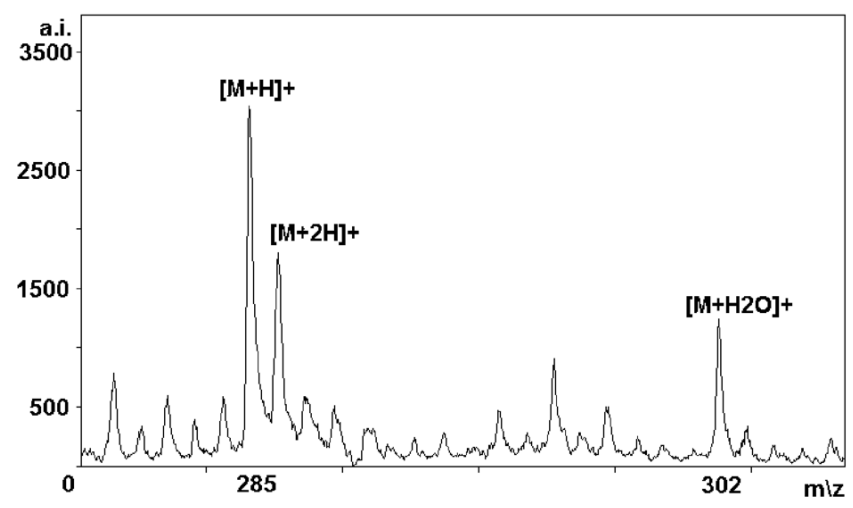

Рис. 3. Мас-спектр МБ, отриманий шляхом десорбції з поверхні ТРГ для інтенсивності лазера $60 \%$ та часі затримки екстракції $150 \mathrm{HC}$

Гессе кожного з цих станів [11]. Заряди атомів розраховувалися за методом Маллікена.

\section{3. Результати та їх обговорення}

\section{1. Експерименталъна частина}

Розглянемо сукупність спектрів МБ, десорбованого 3 поверхні ТРГ (див. рис. 1-3) водню, як це вже було показано раніше в роботі [2]. В спектрах майже відсутній пік молекулярного катіона МБ, натомість присутні форми, де до первинного катіона приєднані додаткові один, два, або три атоми водню. Це свідчить про достатню кількість відповідних атомів на поверхні ТРГ в умовах мас-спектрометричного експерименту та про можливість їх легкого вивільнення для іон-молекулярних реакцій під дією лазерного опромінення. Ми вважаємо, що джерелом атомів водню є молекули води, адсорбовані в міжплощинному 
просторі ТРГ, наявність яких була доведена в [2] методом температурно-програмованої десорбційної масспектрометрії. Ця властивість суттєво відрізняє ТРГ від інших форм вуглецю. Щодо вивільнення атомів водню з молекул води, то воно може відбуватися в процесі лазерно-стимульованого окиснення поверхні ТРГ.

На рис. 1 наведено мас-спектри для трьох значень відносної інтенсивності лазерного опромінення (40\%, $60 \%, 100 \%$ ) та часу затримки екстракції 20 нс. В масспектрах звертає на себе увагу відносно невеликий пік від молекулярного катіона $\mathrm{M}^{+}$, а найбільш імовірним є утворення форми МБ з приєднаним одним атомом водню з масою 285 а.о.м.

Факт переважного утворення іона $[\mathrm{M}+\mathrm{H}]^{+}$для метиленового блакитного в ході лазерно-десорбційної іонізації добре відомий. Але в наведених мас-спектрах наявний також пік з масою 286 а.о.м., 3 інтенсивністю, яка суттєво перевищує очікуваний внесок в інтенсивність за рахунок ізотопу $\mathrm{C}^{13}(17 \%)$. Цей факт примушує припустити внесок в мас-спектр іонів складу $[\mathrm{M}+2 \mathrm{H}]^{+}$. Аналогічна ситуація спостерігається i для маси 287, що приводить до можливості існування іонів складу $[\mathrm{M}+3 \mathrm{H}]^{+}$. Не виключено існування катіонів з більшою кількістю атомів водню, але експеримент не дозволяє надійно зареєструвати іони такого складу. Співвідношення інтенсивності піків не залежать суттєво від енергії лазерного опромінення, що наводить на думку, що атоми водню розміщуються поблизу молекули метиленового блакитного заздалегідь, а підвищення енергї опромінення лише прискорює десорбційну іонізацію вже існуючих у конденсованому стані комплексів.

На рис. 2 утворення спостережених іонів наведено для часу, що дорівнює 150 нс перебування іонів над поверхнею, з якої відбувається десорбція іонів в експерименті. Особливості цього спектра слід порівняти 3 рис. 1, $а$, де енергія опромінення лазером була та сама, а час затримки суттєво відрізнявся і дорівнював 20 нс. 3 наведених мас-спектрів випливає, що перебування в іонізованій хмарі над поверхнею терморозширеного графіту приводить до обміну енергією між іонам, внаслідок чого мас-спектрометричні піки стають ширшими, що видається цілком логічним. Одночасно дещо збільшується відносний внесок водень-вмісних іонів, що вказує на те, що приєднання водню до іонів МБ продовжується також і над поверхнею ТРГ.

Найцікавішим фактом, що спостерігається у роботі, нам видається поява в спектрі форми $[\mathrm{M}+3 \mathrm{H}]^{+} .3$ літератури відома здатність МБ до утворення відновлених форм, проте опромінення інших підкладок не приводила раніше до вильоту форм МБ з трьома приєднаними атомами водню. Знайдена нами тут особливість ТРГ як підкладки в мас-спектрометрії може виявитися корисною при подальших дослідженнях тих іонів, які є нестійкими самі по собі, або ж рекомбінують з іншими сполукам, що утруднюе їхню ідентифікацію мас-спектрометричними методами. Для перевірки можливості утворення структури $[\mathrm{M}+3 \mathrm{H}]^{+}$та з'ясування загальних механізмів приєднання кількох атомів водню було проведено квантово-хімічні розрахунки, результати яких наведено нижче в теоретичній частині даної роботи. Вони підтверджують, що утворення сполук, які спостерігалися нами експериментально, не заборонене з точки зору квантової хімії та $є$ достатньо енергетично вигідним.

Як уже зазначалося вище, в усіх без винятку масспектрах виявлено також піки, котрі відповідають молекулярному катіону з приєднаною молекулою води (рис. 3). Наявність такого піка свідчить, на наш погляд, про те, що комплекси в складі молекули МБ і молекули води існують безпосередньо в адсорбованому стані. Оскільки наявність зв'язаної води в ТРГ не викликає сумніву, можна розглянути також можливість, що сполука з декількома атомами водню та приєднаною молекулою води є енергетично невигідною, так що приєднання молекули води до асоціату з двома чи більше атомами водню викликає відокремлення усіх атомів водню. Останнє припущення потребує подальшої окремої перевірки. Зазначимо, що на саму можливість приєднання молекул води до десорбованих з поверхні ТРГ сполук вказувалося раніше [2]. У зв'язку з цим можна припустити, що молекули води виконують стабілізуючу функцію та запобігають фрагментації молекул з великою молекулярною масою під час десорбціі. Втім, умови створення і структура такого катіона потребують додаткових експериментальних досліджень і квантово-хімічних розрахунків.

\section{4. Теоретична частина}

\section{1. Взаємодія атомів водню з катіоном метиленового блакитного}

Як випливає з експериментальної частини даної роботи, в умовах мас-спектрометричного експерименту зафіксовано іони, які утворилися внаслідок дії лазера на зразок, який складався з підкладки ТРГ та адсорбованих на ньому молекул МБ. Зареєстровані іони відповідають брутто формулам: $\left[\mathrm{C}_{16} \mathrm{~N}_{3} \mathrm{H}_{18} \mathrm{~S} \cdot \mathrm{H}\right]^{+}$, $\left[\mathrm{C}_{16} \mathrm{~N}_{3} \mathrm{H}_{18} \mathrm{~S} \cdot 2 \mathrm{H}\right]^{+},\left[\mathrm{C}_{16} \mathrm{~N}_{3} \mathrm{H}_{18} \mathrm{~S} \cdot 3 \mathrm{H}\right]^{+}$. Отже, виникає 


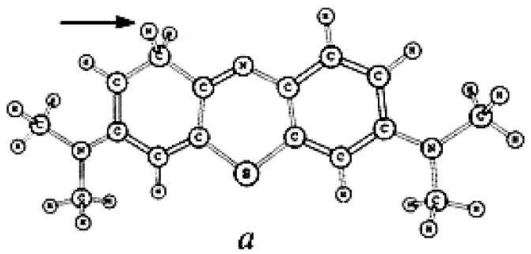

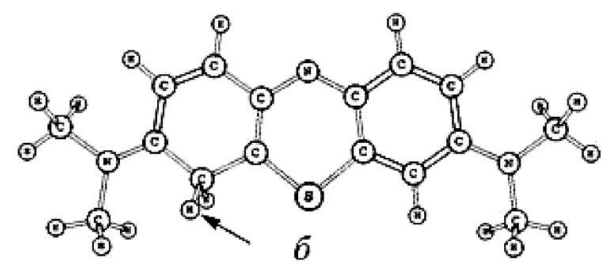

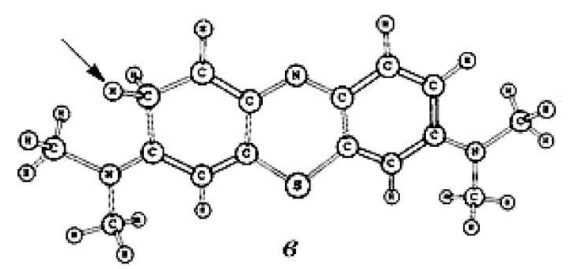

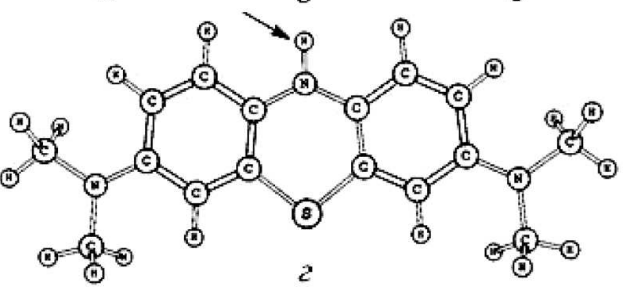

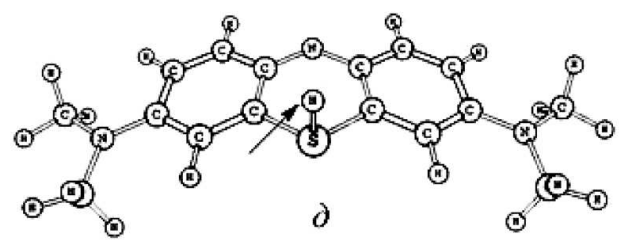

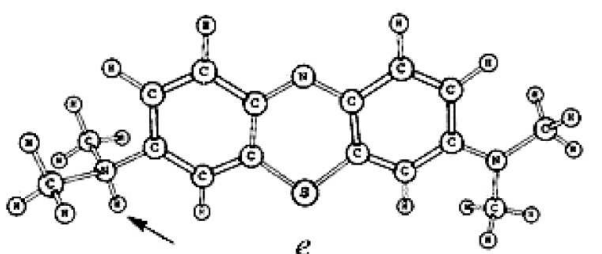

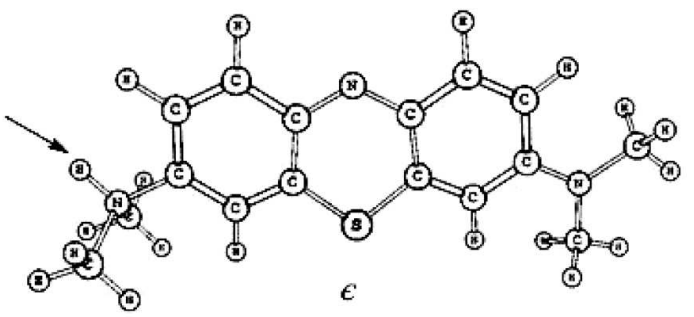

Рис. 4. Можливі структури катіон-радикалів з брутто-складом $\left[\mathrm{C}_{16} \mathrm{~N}_{3} \mathrm{H}_{18} \mathrm{~S} \cdot \mathrm{H}\right]^{+} \mathrm{i}$ масою 285 а.о.м., що можуть утворитись внаслідок взаємодії атома водню з катіоном метиленового блакитного $\left(\mathrm{C}_{16} \mathrm{~N}_{3} \mathrm{H}_{18} \mathrm{~S}^{+}, 284\right.$ а.о.м.), при цьому атом водню може приєднатись до цього катіона в різних місцях

необхідність встановити хімічну будову структур 3 даним брутто-складом.

\section{2. Приєднання першого атома водню до катіона метиленового блакитного}

Внаслідок взаємодії катіона МБ 3 атомом водню останній може приєднуватись до атомів азоту, сірки, або вуглецю ароматичної системи катіона МБ (рис. 4), утворюючи катіон-радикал з брутто-складом $\left[\mathrm{C}_{16} \mathrm{~N}_{3} \mathrm{H}_{18} \mathrm{~S} \cdot \mathrm{H}\right]^{+}$. Нами було розраховано термодинамічні характеристики реакції приєднання: атома водню до катіона МБ, яка відбувається за схемою: $\mathrm{C}_{16} \mathrm{~N}_{3} \mathrm{H}_{18} \mathrm{~S}^{+}+\mathrm{H} \rightarrow\left[\mathrm{C}_{16} \mathrm{~N}_{3} \mathrm{H}_{18} \mathrm{~S} \cdot \mathrm{H}\right]^{+}$. Результати розрахунків наведено в табл. 1.

3 табл. 1 видно, що за стандартних умов найбільше значення вільної енергії Гіббса одержується при утворенні продукту (2), показаному на рис. 4, в якому атом водню зв'язаний з атомом азоту піридино- вого кільця. Внаслідок відповідної реакції при утворенні цієї структури на означеному атомі азоту заряд набуває більш негативного значення, змінюючись від $-0,517$ до $-0,713$ (в одиницях елементарного заряду).

T а б ли ц я 1 . Термодинамічні характеристики реакції приєднання атома водню до катіона метиленового блакитного (МБ). Тут $\Delta E, \Delta G, \Delta H$ та $\Delta S$ означають зміни внаслідок певної реакції (вказаної в першому стовпчику) повної енергії, зміни вільної енергії Гіббса, ентальпії та ентропії, відповідно

\begin{tabular}{c|c|c|c|c}
\hline $\begin{array}{c}\text { Продукт } \\
\text { реакції }\end{array}$ & $\begin{array}{c}\Delta E, \\
\text { кДж/моль }\end{array}$ & $\begin{array}{c}\Delta G, \\
\text { кДж/моль }\end{array}$ & $\begin{array}{c}\Delta H, \\
\text { кДж/моль }\end{array}$ & $\begin{array}{c}\Delta S, \\
\text { кДж/моль }\end{array}$ \\
\hline$a$ & $-146,3$ & $-98,1$ & $-135,5$ & $-125,3$ \\
$\sigma$ & $-146,3$ & $-98,1$ & $-135,5$ & $-125,3$ \\
в & $-198,8$ & $-149,8$ & $-187,2$ & $-125,3$ \\
$z$ & $-250,3$ & $-195,4$ & $-230,5$ & $-117,7$ \\
$\partial$ & $-94,1$ & $-52,4$ & $-86,0$ & $-112,8$ \\
$e$ & $-225,4$ & $-168,7$ & $-210,3$ & $-139,8$ \\
$\epsilon$ & $-225,1$ & $-167,6$ & $-209,9$ & $-141,9$ \\
\hline
\end{tabular}



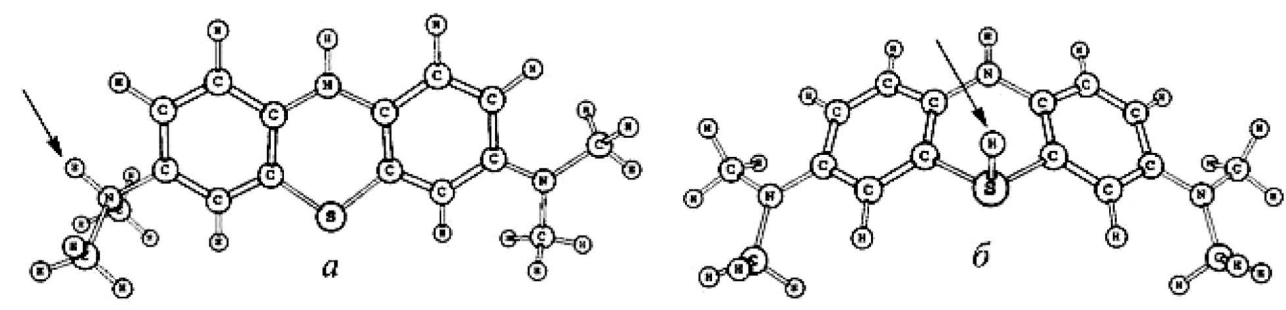

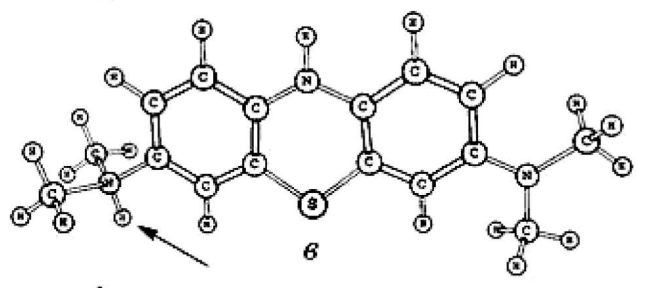

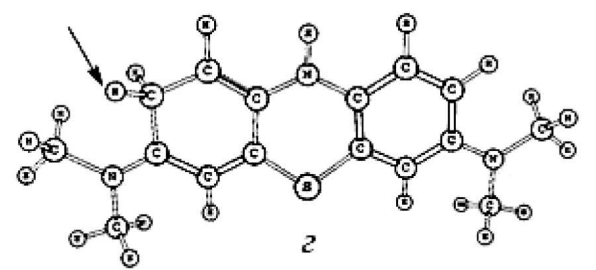

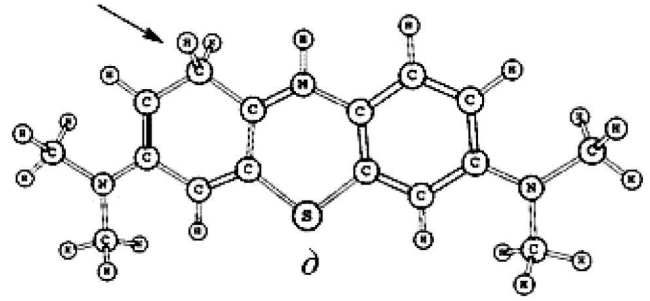

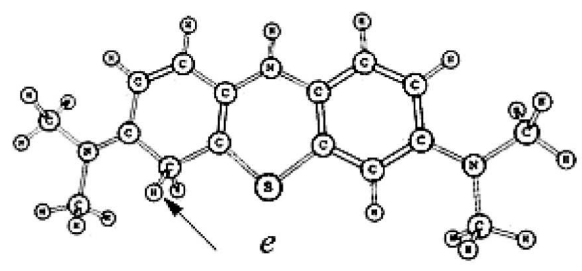

Рис. 5. Можливі структури катіон-радикалів з брутто-складом $\left[\mathrm{C}_{16} \mathrm{~N}_{3} \mathrm{H}_{18} \mathrm{~S} \cdot 2 \mathrm{H}\right]+$ i масою 286 а.о.м., що можуть утворитись внаслідок взаємодії двох атомів водню з катіоном метиленового блакитного $\left(\mathrm{C}_{16} \mathrm{~N}_{3} \mathrm{H}_{18} \mathrm{~S}^{+}, 284\right.$ а.о.м.), при цьому положення першого атома водню зафіксоване, а другий атом може приєднатися в різних місцях

Це свідчить про часткове перенесення електронної густини під час реакції приєднання до катіона МБ 3 атома водню, який набув відносно великого позитивного заряду $(\rho=0,363)$ у порівнянні з усіма іншими атомами водню (від 0,141 до 0,199). При цьому, у первинного катіона МБ найбільш позитивно був заряджений атом сірки $(\rho=0,440)$, а по приєднанні атома водню заряд на атомі сірки зменшився до 0,411. Спираючись на результати наших розрахунків, згідно 3 якими утворення сполуки катіона МБ з атомом водню є вигідним, ця структура була вибрана базовою для дослідження можливості приєднання наступного атома водню.

Т а б л и ц я 2. Термодинамічні характеристики реакції приєднання атома водню до структури $\left[\mathrm{C}_{16} \mathrm{~N}_{3} \mathrm{H}_{18} \mathrm{~S} \cdot \mathrm{H}\right]^{+}$

\begin{tabular}{c|ccccc}
\hline $\begin{array}{c}\text { Продукт } \\
\text { реакціі }\end{array}$ & $\begin{array}{c}\Delta E, \\
\text { кДж/моль }\end{array}$ & $\begin{array}{c}\Delta G, \\
\text { кДж/моль }\end{array}$ & $\begin{array}{c}\Delta H, \\
\text { кДж/моль }\end{array}$ & $\begin{array}{c}\Delta S, \\
\text { кДж/моль }\end{array}$ \\
\hline$a$ & $-179,8$ & $-108,4$ & $-140,3$ & $-107,1$ \\
$\sigma$ & $-73,6$ & $-18,9$ & $-45,2$ & $-88,1$ \\
в & $-179,3$ & $-108,2$ & $-13,8$ & $-106,1$ \\
2 & $-146,7$ & $-78,8$ & $-121,3$ & $-142,4$ \\
$\partial$ & $-121,6$ & $-57,4$ & $-86,9$ & $-98,8$ \\
$e$ & $-130,8$ & $-73,2$ & $-96,9$ & $-79,7$ \\
\hline
\end{tabular}

\section{3. Приеднання другого атома водню до структури $\left[\mathrm{C}_{16} \mathrm{~N}_{3} \mathrm{H}_{18} \mathrm{~S} \cdot \mathrm{H}\right]^{+}$}

На рис. 5 зображено можливі продукти приєднання атома водню до структури (2), яка показана на рис. 4, за схемою: $\left[\mathrm{C}_{16} \mathrm{~N}_{3} \mathrm{H}_{18} \mathrm{~S} \cdot \mathrm{H}\right]^{+}+\mathrm{H} \rightarrow\left[\mathrm{C}_{16} \mathrm{~N}_{3} \mathrm{H}_{18} \mathrm{~S} \cdot 2 \mathrm{H}\right]^{+}$. Нами були розраховані термодинамічні характеристики цієї реакції, які наведено в табл. 2. 3 наведених даних видно, що найбільш термодинамічно вигідним є утворення продукту (a) (див. рис. 5), зміна вільної енергії Гіббса при утворенні якого становить $-108,4$ кДж/моль, тобто найнижче значення серед можливих варіантів. Лишень трохи менше змінюється вільна енергія Гіббса реакції $(\Delta G=-108,2$ кДж/моль) при утворенні структури (в). Отже, цей продукт реакції є конформером до структури, показаної на рис. 5,a. А найменш енергетично вигідним, як і в попередньому випадку (табл. 1), є приєднання атома водню до атома сірки структури $\left[\mathrm{C}_{16} \mathrm{~N}_{3} \mathrm{H}_{18} \mathrm{~S} \cdot \mathrm{H}\right]^{+}$, показаної на рис. 5,б.

$\mathrm{Y}$ процесі утворення структури, наведеної на рис. $5, a$, також відбувається перенесення електронного заряду до структури $\left[\mathrm{C}_{16} \mathrm{~N}_{3} \mathrm{H}_{18} \mathrm{~S} \cdot \mathrm{H}\right]^{+}{ }_{3}$ атома водню, на якому заряд набуває найбільш позитивного значення $(\rho=0,378)$ внаслідок приєднання до атома азоту амінної групи. В свою чергу, від'ємний заряд "амін- 


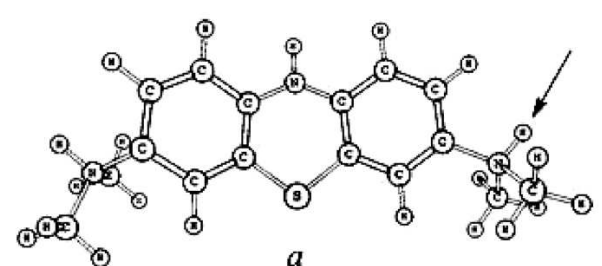

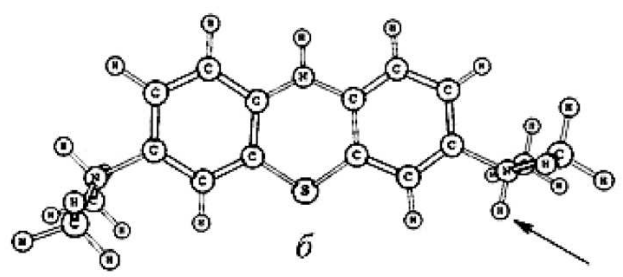

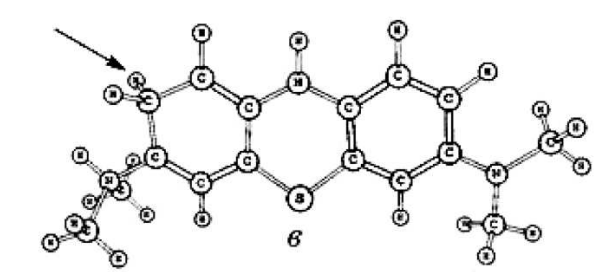

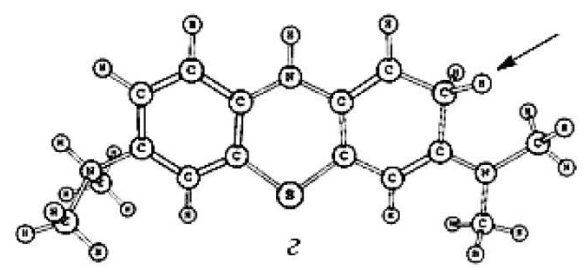

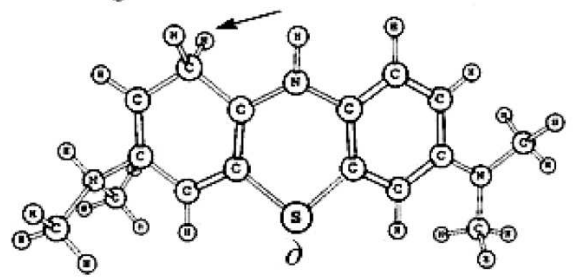

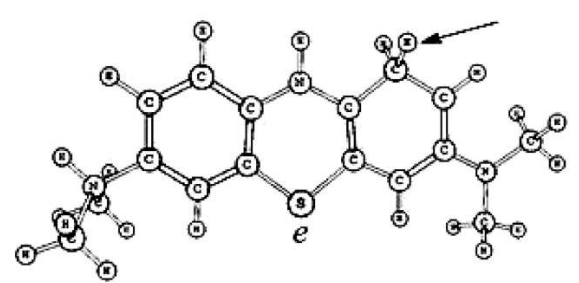

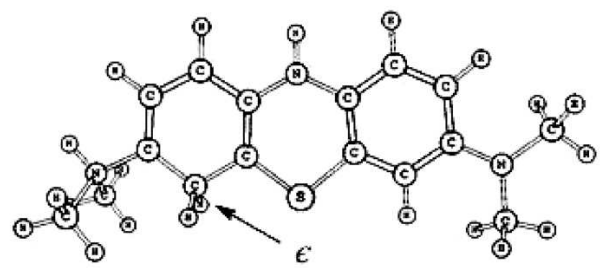

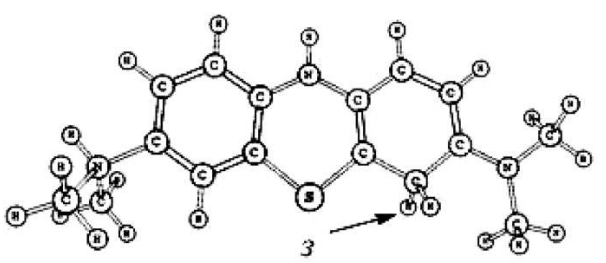

Рис. 6. Можливі структури катіон-радикалів з брутто-складом $\left[\mathrm{C}_{16} \mathrm{~N}_{3} \mathrm{H}_{18} \mathrm{~S} \cdot 3 \mathrm{H}\right]^{+}$i масою 287 а.о.м., що можуть утворитись внаслідок взаємодії трьох атомів водню з катіоном метиленового блакитного $\left(\mathrm{C}_{16} \mathrm{~N}_{3} \mathrm{H}_{18} \mathrm{~S}^{+}, 284\right.$ а.о.м.), при цьому положення першого і другого атома водню зафіксоване, а третій атом може приєднатися в різних місцях

ного" атома азоту зменшується від $-0,729$ до $-0,638$. Максимум електронної густини переноситься від цих атомів на атом сірки, при цьому заряд на ньому стає менш позитивним, змінюючись від 0,411 до 0,310, а також на атом азоту піридинового кільця (заряд набуває негативного значення, більшого на 0,05$)$ i на атом водню, який приєднаний до нього. На цьому атомі водню позитивний заряд також зменшується від 0,363 до 0,315 . Таким чином, внаслідок даної реакції найбільш позитивно зарядженим стає атом водню, що приєднався.

\section{4. Приєднання третъого атома водню до структури $\left[\mathrm{C}_{16} \mathrm{~N}_{3} \mathrm{H}_{18} \mathrm{~S} \cdot 2 \mathrm{H}\right]^{+}$}

Оскільки при взаємодії двох атомів водню з катіоном МБ найбільш імовірним (вигідним) з термодинамічної точки зору є утворення продукту, який зображений на рис. $5, a$, то в подальшому розглядалась можливість приєднання третього атома водню саме до цією сполуки, приєднання третього атома водню приводить до утворення катіон-радикала з бруттоскладом $\left[\mathrm{C}_{16} \mathrm{~N}_{3} \mathrm{H}_{18} \mathrm{~S} \cdot 3 \mathrm{H}\right]^{+}$.

На рис. 6 показані можливі шляхи приєднання атома водню до структури $(a)$, яка наведена на рис. 5 , за схемою: $\left[\mathrm{C}_{16} \mathrm{~N}_{3} \mathrm{H}_{18} \mathrm{~S} \cdot 2 \mathrm{H}\right]^{+}+\mathrm{H} \rightarrow\left[\mathrm{C}_{16} \mathrm{~N}_{3} \mathrm{H}_{18} \mathrm{~S} \cdot 3 \mathrm{H}\right]^{+}$. Pe-

Т а б л и ц я 3. Термодинамічні характеристики реакції приєднання атома водню до структури $\left[\mathrm{C}_{16} \mathrm{~N}_{3} \mathrm{H}_{18} \mathrm{~S} \cdot 2 \mathrm{H}\right]^{+}$

\begin{tabular}{c|c|c|c|c}
\hline $\begin{array}{c}\text { Продукт } \\
\text { реакції }\end{array}$ & $\begin{array}{c}\Delta E, \\
\text { кДж/моль }\end{array}$ & $\begin{array}{c}\Delta G, \\
\text { кДж/моль }\end{array}$ & $\begin{array}{c}\Delta H, \\
\text { кДж/моль }\end{array}$ & $\begin{array}{c}\Delta S, \\
\text { кДж/моль }\end{array}$ \\
\hline$a$ & 42,1 & 97,0 & 58,1 & $-130,6$ \\
$\sigma$ & 54,4 & 114,8 & 73,3 & $-139,0$ \\
$\varepsilon$ & $-133,1$ & $-85,8$ & $-121,4$ & $-119,3$ \\
2 & $-154,1$ & $-100,4$ & $-140,1$ & $-132,9$ \\
$\partial$ & $-144,5$ & $-96,6$ & $-132,3$ & $-119,7$ \\
$e$ & $-148,2$ & $-99,7$ & $-137,3$ & $-126,3$ \\
$e$ & $-136,6$ & $-87,4$ & $-123,6$ & $-121,3$ \\
3 & $-154,7$ & $-103,9$ & $-141,3$ & $-125,4$ \\
\hline
\end{tabular}


зультати розрахунків наведені в табл. 3. На перший погляд, виходячи з наведених вище результатів, слід було очікувати, що третій атом водню приєднається саме до атома азоту амінної групи, однак, як видно 3 табл. 3, найбільш імовірним є утворення продукту (3), показаного на рис. 6 (-103,9 кДж/моль), а приєднання атома водню до атома азоту (рис. 6, $a$, б є термодинамічно невигідним (збільшення енергії на 97,0 і 114,8 кДж/моль відповідно).

Внаслідок реакції приєднання третього атома водню до структури $\left[\mathrm{C}_{16} \mathrm{~N}_{3} \mathrm{H}_{18} \mathrm{~S} \cdot 2 \mathrm{H}\right]^{+}$, як і в попередніх випадках, відбувається перерозподіл електронної густини в молекулі. Атом водню, який приєднався, набуває лише невеликий позитивний заряд 0,066, а на атомі вуглецю, до якого відбулось приєднання, негативний заряд зростає від $-0,187$ до $-0,227$. Збільшується на 0,05 негативний заряд також на атомі азоту піридинового кільця, натомість зростання негативного заряду на атомі азоту амінної групи є значно меншим $(\Delta \rho=0,001)$. На атомі сірки, в свою чергу, заряд став менш позитивним (змінюється від 0,310 до 0,305), а на атомах водню, які приєднані до "амінного" та "піридинового" атомів азоту, електронна густина майже не змінюється, а саме, позитивний заряд збільшується на 0,001 і на 0,002, відповідно. Отже, в даній структурі найбільший позитивний заряд зосереджений на атомі водню, який приєднаний до атома азоту амінної групи $(\rho=0,379)$, а найбільший негативний заряд - на атомі азоту піридинового кільця $(\rho=0,834)$. Попри всю важливість термодинамічного аналізу можливості появи певних продуктів у масспектрах, треба завжди мати на увазі, що співвідношення інтенсивності піків різних іонів, яке спостерігається в експерименті, може залежати (іноді, суттєво залежати) від кінетичних чинників, зокрема, від часів життя відповідних іонів [12].

\section{5. Висновки}

Експериментально доведено, що поверхня ТРГ є активним донором атомів водню та молекул води в процесі іонізації досліджуваної молекули МБ. В процесі лазерної десорбціі/іонізації переважна кількість іонів спостерігається у вигляді катіонів МБ з приєднанням молекули води або атомів водню, при низькій інтенсивності іонів-фрагментів. Таким чином, ТРГ може бути перспективним матеріалом для мас-спектрометричних досліджень складних молекул. Можливість розділити в часі процеси іонмолекулярних реакцій, які відбуваються в гарячій плямі, дозволяє ефективно вивчати процеси взаємо- дії різних іонів та молекул після їхньої десорбції з поверхні. Зазначимо, що приєднання трьох атомів водню до катіона МБ раніше не спостерігалося і є унікальною властивістю ТРГ. Отримані в цій роботі експериментальні результати підтверджені відповідними квантово-хімічними розрахунками.

Зокрема, за допомогою методів квантової хімї вказано на термодинамічно вигідні продукти взаємодії катіона МБ з атомами водню. Встановлено, що перший атом водню утворює ковалентний зв' язок з “піридиновим" атомом азоту катіона МБ з енергетичним ефектом $\Delta G_{\text {реакції }}=-195,4$ кДж/моль, а наступний атом водню взаємодіє з "амінним" атомом азоту попереднього продукту, який має брутто-склад $\left[\mathrm{C}_{16} \mathrm{~N}_{3} \mathrm{H}_{18} \mathrm{~S} \cdot \mathrm{H}\right]^{+}$, $з$ меншою зміною кількості вільної енергії Гіббса (-108,4 кДж/моль). А третій атом водню взаємодіє вже з атомом вуглецю спряженої (циклічної) системи, при цьому виділяється трохи менше вільної енергії Гіббса (-103,9 кДж/моль). 3 цього випливає, що приєднання кожного наступного атома водню до катіона метиленового блакитного стає менш вигідним процесом.

1. Ю.І Семенцов, А.Й. Сенкевич, Г.П. Приходько, М.Л. Пятковський, В.В. Янченко, Н.А. Сировина та матеріали. Хімічна промисловість України 2, 19 (2007).

2. С.В. Снегір, Лазерно-десорбційна мас-спектрометрія комплексів біометалів з органічними лігандами на поверхні вуглецввмісних матеріалів Дисертація канд. фіз.-мат. наук: 01.04.18 (Київ, 2009).

3. А.А. Чуйко, В.А. Покровский, О.И. Козик, Докл. АН УССР. Сер. Б. Геол., хим. и биол. Науки, число 5, 49 (1989).

4. Т.В. Фесенко, М.В. Косевич, Н.И. Суровцева, В.А. Покровский, А.М. Еременко, Н.П. Смирнова, Теорет. эксперим. хим. 43, 220 (2007).

5. B. Lévy and M. Enescu, J. Molec. Struct: Theochem 432, 235 (1998).

6. A.D. Quintão, K. Coutinho and S. Canuto, Int. J. Quant. Chem 90, 634(2002).

7. А.Т. Лебедев, Масс-спектрометрия в органической химии (Бином, Москва, 2003).

8. M.W.Schmidt, K.K. Baldridge, J.A. Boatz, T. Elbert, M.S. Gordon, J.H. Jensen, S. Koseki, N. Matsunaga, K.A. Nguyen, S. Su, T.L. Windus, M. Dupuis and J.A. Montgomery, J. Comput. Chem. 14, 1347 (1993).

9. Г.М. Жидомиров, А.А. Багатурьянц, И.А. Абронин, Прикладная квантовая химия. Расчеты реакиионной способности и механизмов химических реакций (Москва, Химия, 1979). 
10. D.J. Wales and R.S. Berry, J. Chem. Soc. Faraday Trans 88, 543, (1992).

11. F. Jensen, Introduction to computational chemistry 2nd edition (John Wiley \& Sons, New York, 2007).

12. J. Gross, Mass Spectrometry. A Textbook (Springer, Berlin, 2004).

Одержано 16.12.11

ЭКСПЕРИМЕНТАЛЬНЫЕ И ТЕОРЕТИЧЕСКИЕ

ИССЛЕДОВАНИЯ ЛАЗЕРНОЙ ДЕСОРБЦИИ/ИОНИЗАЦИИ МЕТИЛЕНОВОГО ГОЛУБОГО С ПОВЕРХНОСТИ ТЕРМОРАСШИРЕННОГО ГРАФИТА

В.А. Габович, В.А. Покровский, Е.М. Демъяненко,

А.Г. Гребенюк

P е $з$ ю м е

Получены масс-спектры продуктов лазерной десорбции/ионизации красителя метиленового голубого с поверхности терморасширенного графита. В частности показано, что в масс-спектрах наиболее интенсивными являются ионы $[\mathrm{M}+1]^{+},[\mathrm{M}+2]^{+},[\mathrm{M}+3]^{+}$, с присоединенными к молекулярному иону одним, двумя или тремя атомами водорода. Экспериментальные результаты подтверждены квантово- химическими расчетами возможных продуктов, которые могут образоваться под действием лазерного излучения

\section{EXPERIMENTAL AND THEORETICAL STUDIES}

OF LASER DESORPTION/IONIZATION

OF METHYLENE BLUE FROM THE SURFACE

OF THERMALLY EXFOLIATED GRAPHITE

V.A. Gabovich, V.A. Pokrovsky, E.M. Demianenko,

A.G. Grebenyuk

O.O. Chuiko Institute of Surface Chemistry,

Nat. Acad. of Sci. of Ukraine

(17, General Naumov Str., Kyiv 03164, Ukraine;

e-mail:v.gabovich@gmail.com)

$\mathrm{S} u \mathrm{~m}$ m a r y

Mass spectra of products obtained in the course of laser desorption/ionization of methylene blue from the surface of thermally exfoliated graphite have been registered. It is demonstrated that $[\mathrm{M}+1]^{+},[\mathrm{M}+2]^{+}$, and $[\mathrm{M}+3]^{+}$ions with one, two, or three, respectively, hydrogen atoms bound to the molecular ion dominate in the mass spectra. The experimental results are confirmed by quantum chemical calculations of possible reaction products that may be formed under the influence of laser radiation. 